\title{
Tunneling: Evidence from Family Business Groups of Pakistan
}

\author{
Shahid Hussain ${ }^{1}$, Nabeel Safdar ${ }^{2}$
}

\begin{abstract}
This paper investigates a critical aspect of agency conflict between dispersed minority and majority (controlling) shareholders in firms affiliated withfamily business groups. Corporate governance literature indicates that majority shareholders can exploit minority shareholders through tunneling the resources for their benefit or they provide insurance through propping to group firms in distress. For years 2009-2013, the study uses a unique hand-picked data set of 290 non-financial (i.e. 177 family business group and 113 stand-alone or non-group) firms listed on Pakistan Stock Exchange (PSX). The study finds that majority shareholders expropriate minority shareholders by tunneling (transferring) important resources from low cash-flow rights firms affiliated with family business group. While measuring the sensitivities of firms to the industry earnings shocks, the empirical results reveal that about 15\% resources of low cash-flow rights firms are tunneled to high cash-flow rights firms in family business groups. It is also confirmed that equity held by directors representing majority shareholders has negative relationship with earnings of minority shareholders in low cash-flow rights firms affiliated with family business groups. These findings have certain policy implications for governance related regulation development, diverse shareholders and firm management.
\end{abstract}

JEL Classification: G28,G32,G38,M48

Keywords: Tunneling, business groups, corporate governance, ownership concentration.

\section{Introduction}

Business groups exist globally especially in the developing countries having weak protection of minority shareholders. In many countries ${ }^{3}$, such business groups dominate industrial activity of the private-sector (Kali \& Sarkar, 2011). Controlling

1 PhD Scholar, NUST Business School,National University of Sciences and Technology, Islamabad, Pakistan.Email: shahid.hussain@nbs.nust.edu.pk

2 Assistant Professor, NUST Business School, National University of Sciences and Technology, Islamabad, Pakistan.Email: nabeel.safdar@nbs.nust.edu.pk

3 South Africa (Africa); Brazil and Chile (South America); South Korea, Indonesia, Malaysia, Hong Kong, and Taiwan (East Asia); Pakistan and India (South Asia).

\begin{tabular}{lll}
\multicolumn{2}{l}{ ARTICLE HISTORY } \\
$17 \mathrm{Jan}, 18$ & Submission Received & $6 \mathrm{Mar}, 18$ First Review \\
\hline $13 \mathrm{Mar}, 18$ & Revised Version Received & $12 \mathrm{Apr}, 18$ Second Review \\
\hline $15 \mathrm{Apr}, 18$ & Revised Version Received & $30 \mathrm{Apr}, 18$ Accepted
\end{tabular}


or majority shareholders in these business groups have either cross-shareholdings ${ }^{4}$ in group affiliated firms or control these firms through a chain of ownership structures like a pyramid. The head of such business group is normally a family which sequentially controls the firms in the chain; therefore, these business groups are known as family business groups (Claessens, Djankov, \& Lang, 2000; La Porta, Lopez-De-Silanes, $\&$ Shleifer, 1999). A large stream of literature has discussed issues associated with corporate governance in family business groups. Resultantly, two opposing views on family business groups have been emerged; first, family business groups underperform or expropriate resources (Johnson, La Porta, Lopez-de-Silanes, \& Shleifer, 2000) and second, family business groups add value or involve in propping (Friedman, Johnson, \& Mitton, 2003; Khanna \& Palepu, 1997, 2000).

The literature on tunneling view shows highly concentrated ownership in most family business groups which provides strong power to majority or controlling shareholder (i.e. generally a family). Since that voting power or control is larger than their ownership (i.e. cash-flow rights); therefore, majority or controlling shareholders have enough motivation to expropriate or tunnel resources within a family business group. Such transfer of resources benefits majority shareholders at the cost of diverse minority shareholders (Bertrand, Mehta, \& Mullainathan, 2002; Claessens et al., 2000; La Porta et al., 1999). This process of transactions where controlling shareholder transfer or expropriate resources from low cash-flow-rights firms of a family business group to high cash-flow-rights firms in that group is known as "Tunneling" (Johnson et al., 2000; La Porta et al., 1999, 2000).

The opposite of 'tunneling' is called 'propping' or 'negative tunneling' i.e. majority shareholders inject necessary resources to group affiliated firms when these firms are in distress. The proponents of the value addition and propping have alternative views that family business groups provide "mutual insurance" (Friedman et al., 2003; Khanna \& Palepu, 1997, 2000). It means, firms in distress are expected to be injected or propped up by majority shareholders (controlling owners) or comparatively financially stable associated group firms. Riyanto and Toolsema (2008) define that propping is the 'reverse of tunneling'. They highlight that controlling owners use propping to prevent the distressed group firm from bankruptcy. Literature shows that propping involves reallocation of capital within family business group firms to protect distressed group firms and propping is predominant where capital markets are under developed. Therefore, controlling owners have potential incentives to prop up resources today for getting future benefits from profits of distressed firms (Friedman et al., 2003; Hoshi \& Kashyap, 2004; Hoshi, Kashyap, \& Scharfstein, 1990; Morck \& Nakamura, 2005).

4 Cross shareholding refers to a situation in which a listed company owns shares of another listed company. 
Typically, the literature on agency problems has largely been focusing on the conflict between dispersed shareholders and executives or management of firms (Berle \& Means, 1932; Jensen \& Meckling, 1976). In last decade, focus of research in corporate governance (especially agency problems) has been shifted from inherent conflict of interest between dispersed shareholders and firm management to the conflict of interest between majority (controlling) and minority shareholders. Literature suggests that well-dispersed shareholding is comparatively uncommon in most of the Asian and European firms (Faccio, Lang, \& Young, 2001). Resultantly, the expropriation of minority shareholders by majority shareholder has developed the significant agency issue especially in Pyramids (Bertrand \& Mullainathan, 2003).

In this context, this study focuses on Pakistani firms. Although, Pakistan is a common law country but its corporations are predominantly controlled by certain families. Such families control their businesses through cross-shareholding, interlocked-directorships and pyramids (Amjad, 1982; Ashraf \& Ghani, 2004; Cheema, 2003; White, 1974). The high ownership concentration in control of few families ${ }^{5}$ exercising control on many family business group firms creates diversion of control and ownership rights. Such diversion suggests the presence of corporate governance issues in Pakistani corporations especially expropriation of opportunities (Johnson et al., 2000; La Porta et al., 1999, 2000).

In addition, substantial literature on two major competing behaviors of controlling owners in family business groups of emerging markets is available. However, despite existence of concentrated ownership structures of family business groups in Pakistan, no considerable research in this area exist. Though, a study by Ikram and Naqvi (2005) mention about existence of tunneling in Pakistan. However, that study has shortcomings due certain limitations ${ }^{6}$; particularly, it could not present clear and

5 Shahid ur Rahman. (1998). Who Owns Pakistan,Fluctuating fortunes of business Mughals, The University of Michigan p,16-17.

6 Ikram and Naqvi (2005) mention in their study that "Column 1 in Table 2 shows the result that we obtain upon estimation. Contrary to our expectation, the 3 estimate we obtain is 0.6087 ,i.e. positive. Even when we control for the possible differential sensitivity of group firms to their total assets and then their age in Columns 2 and 3 respectively,we do not get much different results. What this seems to suggest is that group firms are,on average,more sensitive to their own group shock. Moreover, we obtain a negative coefficient on 2, which suggests that an increase in mean industry profitability reduces the earnings of standalone firms. Again,this result is contrary to what one our theory suggests. Clearly, if standalone firms are not subject to tunneling,then their earnings should correspond very highly with change in fundamental earnings. Our results seem to suggest otherwise. While this may lead one to question the validity of our hypothesis and/or the specification of our regression, we believe that there are at least two reasons why these results should be looked at doubtfully. Firstly, the results of this regression are extremely sensitive to the correct identification of group firms and standalone firms. While the sources through which we have been able to identify firms as belonging to certain groups are quite reliable, the same cannot be said of standalone firms. In other words, it is quite possible that a particular firm that we have identified as a standalone firm is actually a group firm. This may be one reason why both and coefficients may not be reflecting the true sensitivities of firms' earnings to the industry shock. Secondly,the 
conclusive evidence of tunneling as per the adopted methodology of Bertrand et al. (2002). For example, the signs of the regression coefficients as obtained in the study are opposite to the adopted methodology but study still conclude the existence of tunneling ${ }^{7}$. Secondly, its sample size ${ }^{8}$ is much smaller and it does not truly represent the population as most of its sample firms are listed on Lahore Stock Exchange (i.e. it is much smaller than the Pakistan's the largest exchange i.e. Karachi Stock Exchange (KSE). Resultantly, many essential business group firms listed on KSE are not included in that study, suggesting the possibility of misleading results.

On 11 January 2016, all the three stock exchanges of Pakistan i.e. Karachi Stock exchange (KSE) incorporated on 10 March 1949; Lahore Stock Exchange (LSE) incorporated on 5 October 1970 and Islamabad Stock Exchange (ISE) incorporated on 25 October 1989 have been integrated into KSE. The new single stock exchange of the country is renamed as Pakistan Stock Exchange (PSX). Previously, three stock exchanges were functioning as non-profit companies with mutualized structure. This structure had inherent potential for conflict of interest as members had ownership (controlled affairs of stock exchanges) as well as trading rights. To overcome this issue and to bring more international investments; the Stock Exchanges (Corporatization, Demutualization and Integration) Act, 2012 was enforced by the Securities and Exchange Commission of Pakistan (SECP). Following this Act, all three stock exchanges have been duly corporatized and demutualized with a status as public limited companies. Under this Act, it was obligatory for the stock exchanges to acquire strategic investment. However, they were unable to attract required investments in given time frame even during extended period. Resultantly, after approval of the Scheme of Integration by the Securities and Exchange Commission of Pakistan (SECP); ISE and LSE had been ceased to operate as stock exchanges. However, they still continue as public limited companies (non-banking financial companies.)

Such background of Pakistani corporations and little research in this area provides the stimulus to carry out a comprehensive study to investigate whether tunneling or propping exist in Pakistani family business groups firms and what impact it has on minority shareholders. By using Bertrand et al. (2002) methodology, this study examines the existence of tunneling through measuring the earning shocks (variations)

data set on the basis of which we have derived our results does not have as many observations on standalone firms as it does on groups and group firms. This is one reason why the $\beta 2$ and $\beta 3$ values change significantly once the specification of the regression is changed slightly,e.g. by controlling for assets and time. With a greater number of observations on the number of standalone firms (and with their correct identification), we can hope to get results that are more indicative of the actual picture",CMER working paper,5 (41),p. 10-11.

7 Despite contrary results of the study highlighted above, Ikram and Naqvi (2005) conclude that "The results that we have obtained are indicative of the fact that tunneling is indeed prevalent in Pakistani business groups",CMER working paper,5 (41),p. 13.

8 The authors used data of 86 group-affiliated firms and 29 standalone firms. 
while using the firm-level fixed effects and time dummies to restrict or control for time-invariant firm heterogeneity. The results show the significant existence of tunneling in family business group firms of Pakistan. The regression results show that about $15 \%$ resources are expropriated from low to high cash-flow rights family business groups firms. Moreover, in a family business group firm, 1 percent increase in equity stake of directors, executives and related parties results in 2.38 percent decrease in earnings of minority shareholders related to low cash-flow rights firms of that family business group. The results also show that due significant ownership difference in family affiliated business group firms and non-group (stand-alone) firms; stand-alone firms have less likelihood of tunneling.

The following section 2 presents the review of relevant literature. The section 3 of this paper describes data, models and methods along with development of ownership structure of a family business group. The section 4 analyses and discusses the empirical results and finally section 5 concludes the paper.

\section{Literature Review}

Initially, Johnson et al. (2000) mention about the tunneling. They categorize the tunneling in two major types i.e. "self-dealing transactions" and "financial transactions". The self-dealing transactions are such transactions through which controlling owners expropriate resources for their own benefit. The examples of this type of tunneling are: the assets sales to connected parties at different from market price, transfer pricing ${ }^{9}$, expropriation of corporate opportunities, excessive executive compensation, loan guarantees or loans with in group and so on. The examples of the tunneling related to financial transactions are: insider trading ${ }^{10}$, dilutive equity offerings ${ }^{11}$, minority freeze-outs ${ }^{12}$, creeping acquisitions ${ }^{13}$ or other discriminatory actions against dispersed minority shareholders (Johnson et al., 2000).

This is an important agency problem because the existence of tunneling affects

9 Transfer pricing refers to the price at which various divisions of a company or different companies of same business group transact with each other e.g. the trade of labor and supplies between departments or associated companies. Ideally,transfer prices should not vary from the market price otherwise one of the entities will loss in such transactions.

10 Insider trading refers to the trading of a security by a person who has access to material undisclosed information of that security.

11 Dilution is phenomenon when companies issue new shares to increase their total shares. Resultantly, the company's earnings are further split while diluting the equity of existing shareholders.

12 Minority freeze out refers the steps taken by the majority shareholders to compel minority shareholders for selling their shares in that company.

13 Creeping acquisitions refer to such successive purchase of shares by investors through many small and consecutive transactions which significantly increase their shareholdings in that company without any specific disclosure by the investors. 
the outside shareholders by reducing their returns as well as impedes financial development and market growth. Therefore, tunneling not only affects the minority shareholders rather it also results in less transparent economy, presents the engineered accounting records, deludes the investors and makes it considerably difficult to authenticate the real performance of affected firms (Bertrand et al., 2002). The research shows that one of the reasons that market could not assess the solvency of firms during Asian financial crises of 1997-1998, was the presence of tunneling in corporations of affected countries. In this regard, Johnson, Boone, Breach and Friedman (2000) state that better legally protected markets are less affected by Asian crises.

Literature suggests that expropriation through concentrated pyramidal ownership structures may results in economic consequences at a macro as well as micro levels. The currency depreciations during the financial crisis of 1997 in East Asia reflecting the less protection of minority shareholders is an example of a macro level economic consequence of expropriation (Johnson et al., 2000). The economic consequence at a micro level is best illustrated by the significant impact of information disclosure and ownership structure on cross-sectional stock returns during the financial crisis (Mitton, 2002). Similarly during the financial crisis in Korea, Korean Chaebols (business groups firms) with concentrated ownership underwent the largest value losses (Baek, Kang, \& Park, 2004).

Baek, Kang, and Lee (2006) analyze firms related to Korean Chaebol and find that private securities offerings (linked to equity) are also a means of tunneling. They discover that Korean Chaebols issuers set the offering prices such that it profits their majority shareholders. Djankov, La Porta, Lopez-de-Silanes, and Shleifer (2008) find that connected party transactions may offer direct opportunities to majority shareholders to expropriate financial resources from companies. By using the difference between accounts receivable and payable to connected parties as a proxy for expropriation (tunneling); Gao and Kling (2008) illustrate that this measure is associated with corporate governance characteristics.

Berkman, Cole, and Fu (2009) measure tunneling for loan guarantees that are given by Chinese firms to their controlling block holders. They find that such transactions have lower probability in state-controlled firms. They detect that many listed companies were explicitly expropriated by the issuance of loan guarantees to their controlling block holders. Cheung, Jing, Lu, Rau, and Stouraitis (2009) investigate connected party transactions of controlling shareholders in listed companies of China. They find the evidence of tunneling as well as propping in these companies. However, tunneling is relatively significant than propping up.

By examining the listed firms of China for the period of 1996-2006, Jiang, Lee, 
and Yue (2010) find that controlling shareholders use inter-corporate loans as means to siphon considerable amount. They state that use of inter-corporate loans is an effective way of tunneling. They find significant loss to the minority shareholders of firms with high other receivables balances. Fan, Wei, and Xu (2011) highlight that business groups in emerging markets involve in various internal transfer activities which include physical assets, materials, labor and financial resources and these activities cannot be easily monitored from outside.

Claessens and Burcin (2013) state that many of emerging markets have family owned firms which increase the corporate governance related system-wide problems. However, the nature of such problems differ according to the ownership structure of firms. They also mention that significant deviation between voting (control) rights and cash flow rights of controlling owners exists in East Asian corporations with pyramid structures. Byun, Choi, Hwang, and Kim (2013) conclude that Korean business groups firms have comparatively lower cost of debt and they have unique role in debt market. Pindado and Requejo (2015) argue that the way in which controlling families structure their business groups companies have corresponding influence on the corporate performance. In a study after Asian Financial Crises of 1997-98, Almeida, Kim, and Kim (2015) find that chaebols shifted financial resources from low to high-growth group member firms.

Besides strong empirical evidence of tunneling in countries having less investors' protection; there is significant evidence that the same controlling owners support a weak firm in a family business group by injecting own resources to avoid its bankruptcy (Friedman et al., 2003). Such transfer of resources in the opposite direction from controlling shareholder to a firm is referred as "Propping" in corporate governance literature. Lensink and Molen (2010) find that affiliation of group is predominantly beneficial for firms under financial constraints. The literature about Asian Financial Crisis (1997-1998) provides evidence about the temporarily transferring of resources to a weak listed firm to enhance its financial performance and to avoid a default (Friedman et al., 2003). Khanna and Yafeh (2007) find that family business group firms function similar to parasites who expropriate resources. In small family business groups firms of France, Hamelin (2011) discovers a positive relationship between performance of firms and separation of control from ownership. He also highlights that tunneling improves profit stability (not profit maximization) of controlling shareholders' in small family business groups. Peng, John, and Yang (2011) elucidate that tunneling or propping may take place in the same firm but in different time frame.

In Pakistan, Javid and Iqbal (2010) find the negative relationship between concentration of ownership and corporate governance practices. They conclude that besides other factors, the weak legal environment also led to more concentration of 
ownership in the Pakistani corporations.

\section{Data and Methodology}

\subsection{Sam ple and variables description}

The study uses the hand-picked quantitative data related to accounting ownership and corporate governance. The time horizon of the sample data is 2009 to 2013. The data was manually retrieved from annual financial accounts and relevant websites of 290 (including 117 group affiliated and 113 stand-alone) non-financial firms listed on PSX. Since, many annual reports were not available on websites of companies; therefore, copies of such missing reports were accessed or purchased from the PSX. In addition, some of the data was also collected from State Bank of Pakistan (SBP) and SECP. The ownership data is related to percentage equity of directors, executives and associated companies in all family business groups firms. The ownership values are manually taken from relevant annual reports of the companies. The association of companies is confirmed from the information available on respective websites of companies. Finally, $100 \%$ private ownership of group companies mentioned in ownership structure at Figure 2 is further authenticated from SECP. The complete process of data collection and management reflects the authenticity of the data and ownership information.

The various variables used in the study are described in the following Table 1:

\subsection{Methods and hypothesis development}

Table 1: Variables and Definitions

\begin{tabular}{|c|c|}
\hline Name of Variable & Definition of Variable \\
\hline VR & $\begin{array}{l}\text { The direct and indirect control or voting rights (i.e. equity ownership) of } \\
\text { controlling owners }\end{array}$ \\
\hline CFR & $\begin{array}{l}\text { The direct ownership of controlling owners computed through multiplying } \\
\text { and summing over all related control chains of pyramid ownership structure }\end{array}$ \\
\hline Wedge & The ratio of VR to CFR shows the cash flow leverage of controlling owners \\
\hline GPLtI & $\begin{array}{l}\text { Gross Profit (profits before taxes, depreciation and interest) of firm L at time } \\
\qquad \mathrm{t} \text { in industry I }\end{array}$ \\
\hline$A_{\text {LtI }}$ & Total reported Assets of firm $L$ at time $t$ in industry I \\
\hline $\mathrm{ROA}_{\mathrm{LtI}}$ & $\begin{array}{l}\text { Weighted average Return on Assets of firm } \mathrm{L} \text { at time } \mathrm{t} \text { in relevant industry I } \\
\text { measured as } \mathrm{ROA}_{\mathrm{LtI}}=\mathrm{GP}_{\mathrm{LtI}} / \mathrm{A}_{\mathrm{LtI}}\end{array}$ \\
\hline
\end{tabular}




\begin{tabular}{|c|c|}
\hline $\mathrm{R}_{\mathrm{It}}$ & $\begin{array}{l}\text { Assets Weighted Average Industry Return of all firms measured as } \\
\qquad \mathrm{R}_{\mathrm{It}}=\Sigma_{\mathrm{L}} \mathrm{ROA}_{\mathrm{Ltl}} \times \mathrm{A}_{\mathrm{Ltl}} / \Sigma \mathrm{A}_{\mathrm{Ltl}}\end{array}$ \\
\hline $\mathrm{EE}_{\mathrm{Lt}}$ & $\begin{array}{l}\text { The expected earnings or predicted performance of firm } \mathrm{L} \text { at time } \mathrm{t} \text { in indus- } \\
\text { try } \mathrm{I} \text { measured as } \mathrm{EE}=\mathrm{ALt}{ }^{*} \mathrm{RIt}\end{array}$ \\
\hline $\mathrm{DE}_{\mathrm{L}}$ & $\begin{array}{l}\text { Direct ownership or shareholdings/equity of directors (i.e. directors, CEO, } \\
\text { executives and related family's shareholdings) }\end{array}$ \\
\hline Controls $_{\mathrm{Lt}}$ & $\begin{array}{l}\text { The controls used are Age and Size. The number of years of firm since its } \\
\text { incorporation show the Age. The } \log (\mathrm{Ln}) \text { of firms Assets show the Size }\end{array}$ \\
\hline Firm $_{L}$ & The firm fixed effects dummies \\
\hline Time $_{\mathrm{t}}$ & The years dummies \\
\hline Group $^{\mathrm{L}}$ & $\begin{array}{c}\text { GroupL }=1 \text {, if listed firm is related to family business group and zero other- } \\
\text { wise }\end{array}$ \\
\hline
\end{tabular}

This Table 1 shows the various variables and their definitions used in the study.

In order to investigate the evidence about tunneling in family business groups; the ownership structure of Pakistani family business groups is necessary to understand. Many of the non-financial listed companies are part of the specific group controlled by a particular family. The ownership structure of one such renowned family business group i.e. Dawood family business group is presented in Figure 2 at Appendix I. The ownership structure as shown in Figure 2 is organized manually based on all available information.

The analysis of Dawood business group indicate that Dawood family is the largest shareholder (owns 71.25 \% shares) of the Dawood Lawrencepur Ltd. The Dawood Lawrencepur is the largest shareholder (owns $16.19 \%$ shares) of Dawood Hercules Corporation Ltd and the Dawood Hercules Corporation Ltd is the largest shareholder (owns $28.89 \%$ shares) of Engro Corporation (formerly Engro Chemicals). Finally, Engro Corporation controls 100, 87.10 and $56.20 \%$ of Engro Fertilizer Ltd, Engro Foods and Engro Polymer respectively. The analysis of Engro Corporation shows that Dawood family is the ultimate owner of the Engro Corporation through a chain of pyramid relations as shown in Figure 2. The voting (control) rights of the Dawood family are $37.90 \%$ in Engro Corporation. This value is the sum of percentages shares of director, executives and family equity (i.e. $1.18 \%$ ), and 5.083, 2.741, 0.001 and 28.89 \% shares of Patck Pvt Ltd, Central Insurance Company (CIC), Sach International Pvt Ltd and Dawood Hercules Corporation Ltd respectively. All of these private companies and CIC are fully owned and controlled by the Dawood family.

Following a study by Orbay and Yurtoglu (2006) as bench mark, Voting Rights (VR) or and Cash Flow Rights (CFR) of Dawood Family in Engro Corporation are computed as under: 


$$
\begin{aligned}
& \mathrm{VR}=1.18+5.083+2.741+0.001+28.89=37.90 \% . \\
& \mathrm{CFR}=[(1.18+5.083+2.741+0.001)+28.89 \times\{(0.1001+0.03946+0.00165+ \\
& 0.000015)+0.1619 \times(0.0939+0.05444+0.01161+0.4906+0.00006+0.00262+ \\
& 0.059296)\}]=16.42 \%
\end{aligned}
$$

The CFR are calculated by multiplying and summing over all related control chains of pyramid (Orbay \& Yurtoglu, 2006). The VR (i.e. 37.90 percent) are much more than the CFR (i.e. 16.42 percent). Whereas, Wedge (ie. The ratio of VR to CFR) $=37.90 / 16.42=2.31$. Similarly, the VR and CFR of Dawood family in Dawood Hercules Corporation Ltd are computed as under:

$$
\begin{aligned}
& \mathrm{VR}=10.01+0.0015+0.165+3.946+16.19=30.3125 \% \\
& \mathrm{CFR}=10.01+0.0015+0.165+3.946+\{16.19 \times(0.0939+0.05444+ \\
& 0.01161+0.4906+0.00006+0.00262+0.059296)\}=25.6595 \%
\end{aligned}
$$

VR $/ C F R=30.3125 / 25.6595=1.1814$

The VR and CFR of Dawood family in Dawood Lawrencepur Ltd are computed as under:

$$
\begin{aligned}
& \mathrm{VR}=9.39+5.444+1.161+49.06+0.006+0.262+5.9296=71.2466 \% \\
& \mathrm{CFR} \quad=9.39+5.444+1.161+49.06+0.006+0.262+5.9296=71.2466
\end{aligned}
$$

$\mathrm{VR} / \mathrm{CFR}=71.2466 / 71.2466=1$

The analysis of the ratios of VR and CFR show that cash flow leverage (wedge) of Engro Corporation (i.e. 2.31) is greater than wedge of Dawood Hercules (i.e. 1.18) and Dawood Lawrencepur (i.e. 1). This significant difference of CFR and VR in Engro Corporation provides incentives to controlling shareholder (i.e. Dawood family) to tunnel (transfer) resources from low cash flow rights firm (i.e. Engro Corporation) to high cash flow right firms (e.g. Dawood Hercules Corporation or Dawood Lawrencepur Limited). Johnson et al. (2000) describe such displacement of resources as tunneling which affects the business interests of dispersed minority shareholders in low cash-flow rights family business group-affiliated firms.

The most popular study related to tunneling is by Bertrand et al. (2002) who investigate the tunneling in business groups of India. They regress firms given earnings (as reported in financial statements) against the predicted (expected) earnings. By this methodology, they examine the transmission of earnings shocks (profit variations) between firms of a family business group as per the ownership of majority shareholder 
(controlling owner) in each firm. They find the significant amounts of tunneling in the Indian business groups. Their test of tunneling is based on the argument that by investigating the deviations in the profitability of related industry firms and then measuring the reaction of a particular firm to those deviations, the level of governance of that firm can be measured. This argument is quite appealing and simple as it takes external focal point to examine quality of governance. The examination of tunneling in this study is conducted by following this most popular methodology.

In order to understand the methodology, the Figure 1 presents a model business group in which an ultimate owner i.e. Firm A (or family) has 30 and 40 percent direct controls of upper level firms B and D respectively. Further, these both firms control 50 percent and 20 percent of Firm L respectively. Hence, Firms B and D are directly exercising 70 percent control (i.e. voting rights) on Firm L (i.e. lower level firm) and the ultimate owner (i.e. Firm A, the higher level firm) is indirectly controlling Firm $\mathrm{L}$ through these voting or control rights. Whereas, the direct ownership (cash-flow rights) of the Firm A in Firm L are just 23 percent i.e. (30 percent x 50 percent +40 percent $\times 20$ percent $=23$ percent).

It implies that shifting of resources from firm L (i.e. lower level firm) to firms $\mathrm{B}$ and D (i.e. higher level firms) is more beneficial to firm A (or controlling family)

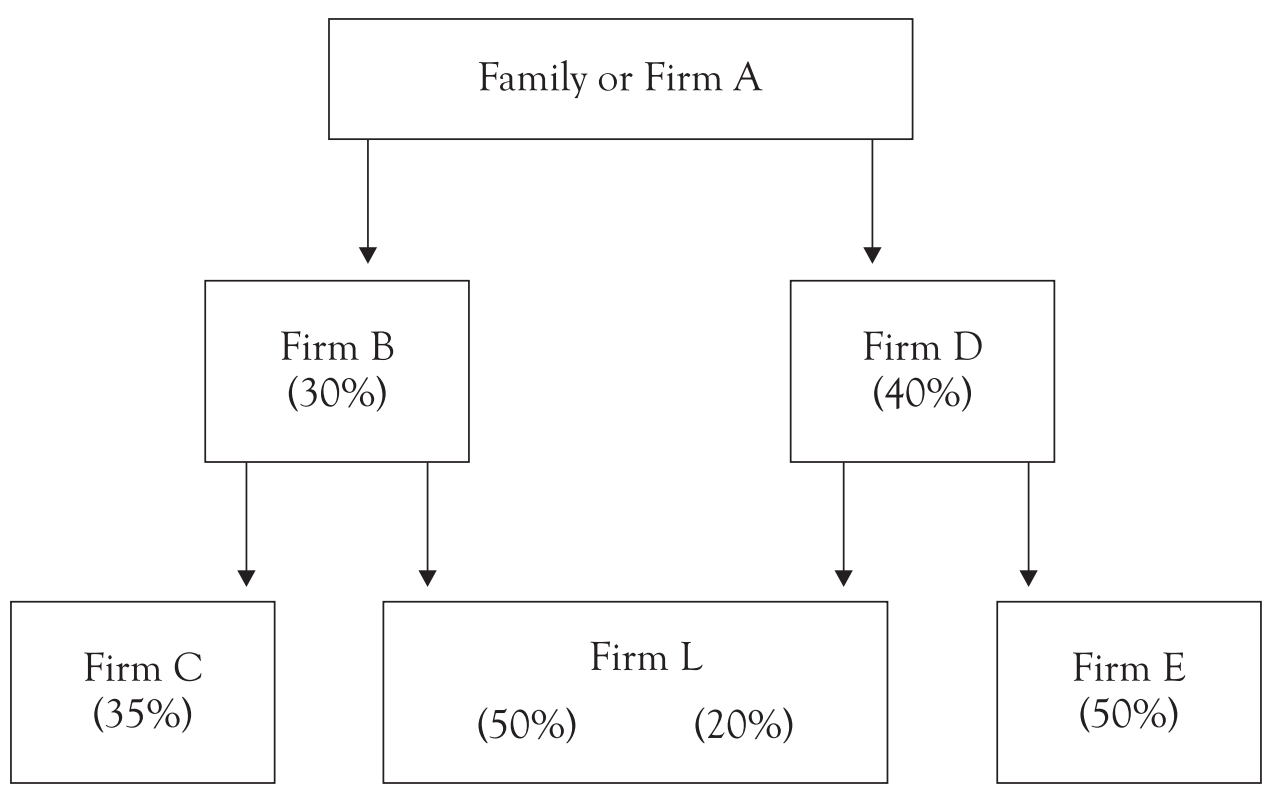

Figure 1: Model Family Business Group Ownership Structure 
where it has comparatively more direct ownership or cash-flow rights. Suppose, there is variation ${ }^{14}$ in industry earnings due to any factor, e.g. demand surge. Suppose this variation in earnings should increase the firm L's earnings by Rs.100. However, the actual increase in reported earnings (on financial statements) of firm is just Rs.75. The question arises, where the remaining amount i.e. Rs.25 has gone?

\subsubsection{Hypothesis 1: Sensitivity to industry profit variations (group vs standalone firms)}

The literature suggests that separation between ownership and control (i.e. cashflow vs voting rights) provides incentives to the majority shareholders to engage in tunneling related transactions which ultimately affect financial interests of dispersed minority shareholders (Johnson et al., 2000). Since the Firm A (i.e. majority shareholder) has comparatively more direct ownership in firm B and D; therefore, the majority shareholder is likely to avail all chances to shift resources from lower cash-flow rights firm $\mathrm{L}$ to firm $\mathrm{B}$ or $\mathrm{D}$. This gives the answer to question above i.e. the amount Rs. 25 actually has tunneled or transferred out of the group firm L to group firms B and/or firm $\mathrm{D}$ in which firm $\mathrm{A}$ has more direct ownership and incentives to transfer resources. This implies that the group firms, on average, will less or under respond to shocks (variations) to their own earnings and it leads to following hypothesis:

H1: In family business groups, listed firms are comparatively less sensitive to earnings shocks or profits variations in relevant industry than stand-alone listed firms.

3.2.2. Hypothesis 2: Sensitivity to industry profit variations by direct cash flow rights (director equity)

Though, majority shareholder has more incentives to shift all or considerable part of valuable resources from firm L; however, the clandestine transfer of resources is the risky and costly due to likelihood of being known to market or dissipation of firm L's resources resulting in more chances of being caught putting the reputation on stake. Nevertheless, the actual transferring of resources will mainly depend upon director equity stake or cash-flow rights of firm A (or controlling family) in firm L. The less ownership in firm L likely to result in less incentive for family/ firm A to leave resources in firm L. Resultantly, it creates more chances of tunneling of resources from firm L (i.e. lower level firm) to firm B or D (i.e. higher level firms). This implies that under response or less sensitivity to shocks (variations) to own earnings should be higher in lower level firms (having low-cash-flow rights) and it leads to our following hypothesis:

H2: In family business groups, firms having high cash-flow rights are expected to reflect higher responsiveness to earnings variations in their industry than firms having low cash-flow

14 Bertrand et al. (2002) refer it as 'Own Shock' due to earning variation in industry. 
rights.

\subsection{Model description}

Literature ${ }^{15}$ suggests, industry movements give the best reflection of actual profits of firm in the normal circumstances i.e. when there is no expropriation of resources. Following the Bertrand et al. (2002), this study measures the variation in profits (industry profit shock) with regard to the mean industry return. In order to find or quantify the tunneling, initially industry shocks are measured followed by computing the predicted or expected earnings (profit) for each firm. This expected earning is based on the earning shock (profit variation) faced by all other firms in the specific industry.

For this purpose, suppose in a particular industry I at time t; gross profits (reported earnings) and assets (total assets) for firm $\mathrm{L}$ are measured by $\mathrm{GP}_{\mathrm{LtI}}$ and $\mathrm{A}_{\mathrm{LtI}}$ respectively. Accordingly, Return on Assets for firm L is measured as $\mathrm{ROA}_{\mathrm{Ltl}}=\mathrm{GP}_{\mathrm{LtI}}$ / $\mathrm{A}_{\mathrm{Ltt}}$. Since, profits variations in industry is ideally described by the industry return; therefore, for all firms in the industry I, asset weighted average return is computed to isolate the earnings shock (variations) in industry. Thus, the industry return is $\mathrm{R}_{\mathrm{It}}=$ $\Sigma_{\mathrm{L}} \mathrm{ROA}_{\mathrm{LtI}} \times \mathrm{A}_{\mathrm{LtI}} / \Sigma \mathrm{A}_{\mathrm{LtI}}$. It implies that in the absence of the tunneling, the earnings of firm's $L$ can be estimated by computing the multiple of assets and industry return i.e. Expected Earnings $(\mathrm{EE})=\mathrm{A}_{\mathrm{LtI}}{ }^{*} \mathrm{R}_{\mathrm{It}}$. In order to avoid the inherent correlation, for every firm, the firm itself has to be excluded in calculating its industry return.

The above process is further described in the following simple way: Initially, the total assets and all profits of a given industry in each year are to be added up (but deducting the profits and assets of the principal company). Then, the industry's ROA for each year is to be calculated (but deducting the ROA of the principal company). This ROA is to be multiplied by the assets of principal company's in that particular year. It would predict the Expected Earnings of the firm given the earnings or profit shock in the industry. In order to find the effect of being a group member in comparison to a non-group firm; the group dummy is then multiplied with this Expected Earnings.

To test the tunneling, the Reported Earnings (i.e. gross profit on profit and loss statement) of firm L are subsequently regressed against its Expected Earnings as well as expected earnings of other firms in a family business groups. Therefore, the following model (1) is used to test the first hypothesis (H1) of the study.

$$
\mathrm{GP}_{\mathrm{Ltl}}=\alpha+\beta\left(E_{\mathrm{Lt}}\right)+\gamma\left(\operatorname{Group}_{\mathrm{L}}{ }^{*} E E_{\mathrm{Lt}}\right)+\delta\left(\operatorname{Controls}_{\mathrm{Lt}}\right)+\text { Firm }_{\mathrm{L}}+\text { Time }_{\mathrm{t}}+U_{\mathrm{Lt}}(1)
$$

Where, dependent variable GP is Gross Profit of firm $L$ at time $t$ in industry $I$.

15 Bertrand et al. (2002) state that although the industry variations affect individual firms; however, they are significantly beyond the control of all individual firms. 
Since the expropriations of resources and profits shocks or variations affect the profits of firm with low-cash-flow rights; therefore, it becomes essential to use some reliable profit figure. Fluctuating stock prices and inadequate dividend figures (which affect the stock prices) and related factors creates the limitations to use other earnings figures. Therefore, the preference of Gross Profit on other profit figures is primarily because the gross profit is comparatively more reliable than other figures.

The $E E_{L t}$ is Expected (predicted) Earnings at time t, the use of dummy variable Group $_{L}$ indicates whether firm $L$ is part of a business group or otherwise, Controls ${ }_{L t}$ variables like size (ln assets) and age (i.e year of incorporation of the firm) are used to check their possible effect on the firm's earnings. Firm fixed effects are indicated through Firm ${ }_{L}$, and time dummies Time $e_{t}$ measure the effect of difference in time period. The sensitivity of firm $L$ to relative profits of industry is measured through regression coefficient $\beta$. The differential sensitivity of firms in business group is measured through regression coefficient $\gamma$. Since, business group firms are usually less sensitive to Expected Earnings shocks, therefore, the less (more) will be the regression coefficient $\gamma$, and the more (less) will be the evidence of tunneling. The shock or earnings variations is basically the change in the expected industry earnings. Again following the Bertrand et al. (2002), it would be tested whether tunneling increases when family business group is controlled by insiders as well as when controlling shareholders exercise control with a comparatively lower percentage of cash-flow-rights or ownership. In order to test the next hypothesis (H2), the model (2) is used:

$$
G P_{L t l}=\alpha+\beta\left(E E_{L t}\right)+\gamma\left(D E_{L}^{*} E E_{L t}\right)+\delta\left(\text { Controls }_{L t}\right)+\text { Firm }_{L}+\text { Time }_{t}+U_{L t}
$$

In this model, all variables are same as in model (1) except that the variable Grou$p_{L}{ }^{*} E E_{L t}$ has been changed with $D E_{L}^{*} E E_{L t}$. This variable shows the direct ownership (cash-flow-rights) in firm $\mathrm{L}$ as measured by the shareholdings or equity of directors (i.e. directors, CEO, Executives and related family's shareholdings). The regression coefficient $\gamma$ measures the differential sensitivity of variations in earnings according to the amount of directors' cash flow stake in firm L. If tunneling exists, regression coefficient $\gamma$ is expected to be greater than zero because in a given group, the high cash-flow-rights firms are expected to show greater sensitivity to industry's profit shocks or variations.

\section{Results and Analysis}

\subsection{Summary statistics}

The Table 2 presents the descriptive statistics of data for the sample firms. The average Age of family business group firm is 34.76 years (which ranges from maximum 
age of 82 and a minimum age of 11 year) as compared to average Age of standalone firm i.e 32.62 (which ranges from maximum age of 80 and a minimum age of 13 year). This age factor highlights the maturity of the sample firms. The average Assets (i.e. Size) of family business group firm is Rs.13, 937 Million in contrast to Rs.6, 674 Million of standalone firm. It implies that average size of the family affiliated business group firms is almost double than stand-alone firms.

Table 2: Descriptive Statistics

\begin{tabular}{|c|c|c|c|c|c|c|c|}
\hline \multirow{2}{*}{ Firms } & Age & Assets & Sales & $\begin{array}{c}\text { Gross } \\
\text { Profit }\end{array}$ & $\begin{array}{c}\text { Expected } \\
\text { Earnings }\end{array}$ & $\begin{array}{c}\text { Director's } \\
\text { Equity }\end{array}$ \\
\cline { 3 - 8 } & Years & $\begin{array}{c}\text { Million } \\
\text { Rs. }\end{array}$ & Million Rs. & Million Rs. & Million Rs. & $\begin{array}{c}\text { Percent- } \\
\text { age }\end{array}$ \\
\hline \multirow{2}{*}{ Mean } & Standalones & 32.62 & $6,674.74$ & $6,401.41$ & 894.10 & 990.91 & 29.91 \\
\cline { 2 - 8 } & Group & 34.76 & $13,937.84$ & $16,872.06$ & $2,695.99$ & $2,639.26$ & 32.88 \\
\hline \multirow{2}{*}{ Median } & Standalones & 27.00 & $1,678.88$ & $1,713.25$ & 187.57 & 253.68 & 23.08 \\
\cline { 2 - 9 } & Group & 31.00 & $3,136.19$ & $3,123.16$ & 394.25 & 439.39 & 29.32 \\
\hline \multirow{2}{*}{ Max } & Standalones & 80.00 & $279,233.00$ & $188,999.00$ & $35,550.69$ & $24,839.70$ & 95.90 \\
\cline { 2 - 9 } & Group & 82.00 & $414,011.00$ & $1,100,120.00$ & $162,666.00$ & $145,223.00$ & 99.90 \\
\hline \multirow{2}{*}{ Min } & Standalones & 13.00 & 17.61 & 0.59 & $(6,632.34)$ & 0.93 & 0.00 \\
\cline { 2 - 9 } & Group & 11.00 & 52.98 & 1.59 & $(4,036.72)$ & 6.66 & 0.00 \\
\hline \multirow{2}{*}{$\begin{array}{c}\text { Std. } \\
\text { Dev. }\end{array}$} & Standalones & 16.58 & $20,516.77$ & $15,886.57$ & $2,542.53$ & $2,219.98$ & 28.32 \\
\cline { 2 - 9 } & Group & 16.07 & $35,546.49$ & $66,554.96$ & $10,327.39$ & $9,508.78$ & 28.15 \\
\hline \multirow{2}{*}{\begin{tabular}{c} 
Prob. \\
\cline { 2 - 8 }
\end{tabular}} & Standalones & 0.00 & 0.00 & 0.00 & 0.00 & 0.00 & 0.00 \\
\cline { 2 - 8 } & Group & 0.00 & 0.00 & 0.00 & 0.00 & 0.00 & 0.00 \\
\hline \multirow{2}{*}{$\begin{array}{c}\text { Sample } \\
\text { Size }\end{array}$} & Standalones & 113 & 113 & 113 & 113 & 113 & 113 \\
\cline { 2 - 8 } & Group & 177 & 177 & 177 & 177 & 177 & 177 \\
\hline \multirow{2}{*}{} & & & & & & & \\
\hline
\end{tabular}

This Table 2 shows the descriptive statistics of variables.

The average Sales of group firm and standalone are Rs.16, 872 Million and 6,401 Million respectively. It shows that sales volume of group firms are almost three times larger than stand-alone firms. Similarly, the average Gross Profit, Expected Earnings and Director's Equities of firms in business groups are considerably larger than that of non-group or standalone firms.

The Table 3 shows the correlation of sample variables. Overall, correlation analysis shows that correlation among explanatory variables is weak. It also reflects that these 
Table 3: Correlation

\begin{tabular}{|c|c|c|c|c|c|c|}
\hline Variables & Firms & Age & Size & GP & EE & DE \\
\hline \multirow{4}{*}{ Age } & Standalones & $1.00^{* * *}$ & & & & \\
\cline { 2 - 7 } & Group & $1.00^{* * *}$ & & & & \\
\hline & All & $1.00^{* * *}$ & & & & \\
\hline \multirow{4}{*}{ Size } & Standalones & $0.12^{* * *}$ & $1.00^{* * *}$ & & & \\
\cline { 2 - 8 } & Group & $0.22^{* * *}$ & $1.00^{* * *}$ & & & \\
\hline & All & $0.18^{* * *}$ & $1.00^{* * *}$ & & & \\
\hline \multirow{4}{*}{ GP } & Standalones & $0.18^{* * *}$ & $0.44^{* * *}$ & $1.00^{* * *}$ & & \\
\cline { 2 - 8 } & Group & $0.12^{* * *}$ & $0.45^{* *}$ & $1.00^{* * *}$ & & \\
\cline { 2 - 8 } & All & $0.12^{* * *}$ & $0.41^{* * *}$ & $1.00^{* * *}$ & & \\
\hline \multirow{4}{*}{ EE } & Standalones & $0.27^{* *}$ & $0.60^{* *}$ & $0.77^{* *}$ & $1.00^{* * *}$ & \\
\cline { 2 - 8 } & Group & $0.13^{* * *}$ & $0.48^{* * *}$ & $0.76^{* * *}$ & $1.00^{* * *}$ & \\
\cline { 2 - 8 } & All & $0.14^{* * *}$ & $0.45^{* * *}$ & $0.91^{* * *}$ & $1.00^{* * *}$ & \\
\hline \multirow{5}{*}{ DE } & Standalones & $-0.13^{*}$ & $-0.12^{* *}$ & 0.01 & 0.06 & $1.00^{* * *}$ \\
\cline { 2 - 8 } & Group & -0.05 & $-0.06^{* *}$ & 0.06 & 0.08 & $1.00^{* * *}$ \\
\hline & All & .001 & $.160^{* * *}$ & 0.004 & .005 & $1.00^{* * *}$ \\
\hline
\end{tabular}

This Table 3 shows the correlation of variables. The * shows $p<0.10$, ** shows $p<0.05$ and *** shows $\mathrm{p}<0.01$.

regression model do not have significant issue of multicollinearity. For example, Age of the firms is weakly correlated with all the explanatory variables. Similarly, Sizes of the firms are also not highly correlated with other variables. In addition, all the explanatory variables are positively correlated with gross profit i.e. dependent variable.

\subsection{Sensitivity to industry profit variations (expected earning shock): group versus standalones}

The Table 4 shows the panel regression results of model (1) with respect to firm (cross sections) fixed effects. The Column A reflects the regression results of the basic model without controls. The results are significant and in accordance with the adopted methodology i.e. coefficient $\gamma$ is negative which shows the existence of tunneling. The Column B include the control variable Size i.e. Ln Assets. With inclusion of Size as control variable, the Earning Shock (coefficient $\gamma$ ) results are again significantly negative. The results of Column B show that Rs.1 earning shock leads to about Rs.1.022 (as $\beta=1.022$ ) increase in income of a non-group (stand-alone) firm. Whereas, the same industry earning shock results in 0.16 smaller increase in family 
business group firm as compared to stand-alone firm. In other words, the increase in profits of a family business group firm is just Rs.84 against the industry earning shock (profit variation) of Rs.100.

Table 4: Sensitivity to Industry Profit Variations (Group vs Standalone Firms)

\begin{tabular}{|c|c|c|c|c|c|c|}
\hline Model Variables & $\mathrm{A}$ & $\mathrm{B}$ & $\mathrm{C}$ & $\mathrm{D}$ & $\mathrm{E}$ & $\mathrm{F}$ \\
\hline \multirow{2}{*}{$\begin{array}{c}\text { Expected Earning } \\
\text { Shock }=\beta\end{array}$} & $0.994^{* * *}$ & $1.022^{* * *}$ & $-0.625^{*}$ & $-0.557^{*}$ & $0.515^{* * *}$ & 0.413 \\
\cline { 2 - 7 } & $(0.062)$ & $(0.063)$ & $(0.334)$ & $(0.333)$ & $(0.083)$ & $(0.359)$ \\
\hline $\begin{array}{c}\text { Expected Earning } \\
\text { Shock }\end{array}$ & $-0.146^{* *}$ & $-0.161^{* * *}$ & $-0.259^{* * *}$ & $-0.270^{* * *}$ & $-0.136^{* *}$ & $-0.160^{* * *}$ \\
\cline { 2 - 7 } & $(0.065)$ & $(0.065)$ & $(0.068)$ & $(0.068)$ & $(0.063)$ & $(0.009)$ \\
\hline \multirow{2}{*}{ SIZE $=\delta$} & & $0.481^{* * *}$ & & $0.452^{* * *}$ & & $0.413^{* * *}$ \\
\cline { 2 - 7 } & $(0.146)$ & & $(0.145)$ & & $(0.143)$ \\
\hline \multirow{2}{*}{$\begin{array}{c}\text { Expected Earning } \\
\text { Shock* SIZE }\end{array}$} & & & $0.065^{* * *}$ & $0.063^{* * *}$ & & 0.006 \\
\hline \multirow{2}{*}{$\begin{array}{c}\text { Expected Earning } \\
\text { Shock* Age }\end{array}$} & & $(0.013)$ & $(0.013)$ & & $(0.015)$ \\
\cline { 2 - 7 } & & & & & $0.009^{* * *}$ & $0.009^{* * *}$ \\
\hline Adjusted R ${ }^{2}$ & 0.958 & 0.958 & 0.958 & 0.959 & 0.959 & 0.96 \\
\hline Firm Fixed Effects & Yes & Yes & Yes & Yes & Yes & Yes \\
\hline
\end{tabular}

This Table 4 show the sensitivity to industry profit variations (group vs standalone firms). The column A shows the regression results of basic Model 1 without control variables. The remaining columns show the regression results of same model with different control variables like Age, Size and interactions terms with Expected Earnings. The * shows $\mathrm{p}<0.10$, ** shows $\mathrm{p}<0.05$ and ${ }^{* * *}$ shows $\mathrm{p}<0.01$. Parenthesis show standard errors.

The industry earning shock (expected earning) suggests that the group firm's (firm L) earnings should have increased at par with the other firms in the industry. However, it shows that about 16 percent of group firm's earnings have been expropriated or dissipated by some means. Resultantly, the minority shareholders of the firm $\mathrm{L}$ are at loss by 16 percent less increase in their profits. This phenomenon indicates the existence and impact of tunneling on minority shareholders. The Columns C, D, E and $\mathrm{F}$ include additional control variables and interactions terms with the Expected Earnings. The results reflect that the coefficient of Expected Earning Shock ${ }^{*}$ Group $=\gamma$ is significantly negative and consistent. It is also evident that size and age of firm significantly affect the responsiveness to earnings shocks. Moreover, the standalone and group firms responsiveness to earning shocks differ significantly. Generally, these regression results support the first hypothesis of study and present the significant evidence about existence of tunneling in business groups. 
Table 5: Sensitivity to Industry Profit Variations (Group vs Standalone Firms)

\begin{tabular}{|c|c|c|c|c|c|c|}
\hline Model Variables & A & B & $\mathrm{C}$ & $\mathrm{D}$ & $\mathrm{E}$ & $\mathrm{F}$ \\
\hline \multirow{2}{*}{$\begin{array}{l}\text { Expected Earning } \\
\quad \text { Shock }=\beta\end{array}$} & $0.980^{* * *}$ & $0.999^{* * *}$ & $-0.767^{* *}$ & $-0.801^{* *}$ & $0.494^{* * *}$ & 0.159 \\
\hline & $(0.063)$ & $(0.063)$ & $(0.340)$ & $(0.338)$ & $(0.084)$ & $(0.365)$ \\
\hline \multirow{2}{*}{$\begin{array}{l}\text { Expected Earning } \\
\text { Shock }^{*} \text { Group }=\gamma\end{array}$} & $-0.136^{* *}$ & $-0.144^{* *}$ & $-0.251^{* * *}$ & $-0.263^{* * *}$ & $-0.125^{* *}$ & $-0.159^{* *}$ \\
\hline & $(0.065)$ & $(0.065)$ & $(0.068)$ & $(0.068)$ & $(0.064)$ & $(0.009)$ \\
\hline \multirow[t]{2}{*}{ Size $=\delta$} & & $0.719^{* * *}$ & & $0.750^{* * *}$ & & $0.671^{* * *}$ \\
\hline & & $(0.163)$ & & $(0.162)$ & & $(0.161)$ \\
\hline \multirow{2}{*}{$\begin{array}{l}\text { Expected Earning } \\
\text { Shock }^{*} \text { Size }\end{array}$} & & & $0.070^{* * *}$ & $0.072^{* * *}$ & & 0.016 \\
\hline & & & $(0.013)$ & $(0.013)$ & & $(0.015)$ \\
\hline \multirow{2}{*}{$\begin{array}{l}\text { Expected Earning } \\
\text { Shock* Age }^{*}\end{array}$} & & & & & $0.009^{* * *}$ & $0.008^{* * *}$ \\
\hline & & & & & $(0.001)$ & $(0.001)$ \\
\hline Adjusted $\mathrm{R}^{2}$ & 0.96 & 0.96 & 0.96 & 0.96 & 0.96 & 0.96 \\
\hline Firm Fixed Effects & Yes & Yes & Yes & Yes & Yes & Yes \\
\hline Time Fixed Effects & Yes & Yes & Yes & Yes & Yes & Yes \\
\hline
\end{tabular}

This Table 5 show the sensitivity to industry profit variations (group vs standalone firms) with inclusion of both firm fixed effects and time fixed effects. The column A shows the regression results of basic Model 1 without control variables. The remaining columns show the regression results of same model with different control variables like Age, Size and interactions terms with Expected Earnings. The ${ }^{*}$ shows $\mathrm{p}<0.10$, ${ }^{* *}$ shows $\mathrm{p}<0.05$ and ${ }^{* * *}$ shows $\mathrm{p}<0.01$. Parenthesis show standard errors.

The Table 5 displays the regression results of model (1) with inclusion of both firm (cross section) fixed effects ${ }^{16}$ and time (year) fixed effects. ${ }^{17}$ The results of this model are again significant and consistent. These results additionally reflect that the time period has very minimal effect on the results of this column because the ownership concentration and business groups' affiliation do not change frequently and remain almost same in adjacent years.

In Table 5, the Column A reflects the regression results of the basic model without controls. The results are significant and same as expected i.e. coefficient $\gamma$ is negative which shows the existence of tunneling. With inclusion of Size as control variable, the Earning Shock (coefficient $\gamma$ ) results are again significantly negative. The results of Column B show that Rs.1 earning shock leads to almost Rs.1 (as $\beta=0.999$ ) increase

16 The firm fixed effect solves the many problems especially endogeneity issue of structural reverse causality (see Demsetz and Lehn,1985). The fixed effect deals with inherent fixed differences between firms. Since,the sample firms remain in the same group (do not change group), therefore, it takes into account the fixed differences between the groups.

17 The year fixed effect captures the variations due to change of time. 
in income of a non-group firm. Whereas, the same industry earning shock results in 0.144 smaller increase in family business group firm as compared to stand-alone firm.

In simple words, the increase in profits of a family business group affiliated firm is just Rs.85 against the industry earning shock (profit variation) of Rs.100. It shows that about 15 percent earnings of family business group are expropriated or dissipated by some means. Resultantly, the minority shareholders of the group firm $\mathrm{L}$ are at loss by 15 percent less increase in their profits. This phenomenon indicates the existence and impact of tunneling on minority shareholders. The Columns C, $\mathrm{D}, \mathrm{E}$ and $\mathrm{F}$ include additional control variables and it is clear that the coefficient of Expected Earning Shock ${ }^{*}$ Group i.e. $=\gamma$ is significantly negative and consistent. It is also evident that size and age of firm significantly affect the responsiveness to earnings shocks. Moreover, standalone and family business group firms' responsiveness to earning shocks differ significantly. Overall, these regression results also support the first hypothesis and show the substantial evidence and impact of tunneling in family business groups firms.

\subsection{Sensitivity to industry profit variations (expected earning shock) by direct cash flow rights (director equity)}

In Table 6, Columns A, B and $\mathrm{C}$ represent the family business group firms and Columns C, D and E are related to standalone firms. The Column A presents the results of the basic regression model (2) without control variables estimated on group firms. The results are significant and positive and in accordance with the literature i.e. the coefficient Expected Earning Shock* Director Equity $=\gamma$ indicates that family business group firms having more directors' equity stake are more responsive to earnings shock (variations) in industry. Conversely, family business group firms with less directors' equity stake (e.g. firm L in Figure 1) are less sensitive to earning shock in their industry.

The Column B include the control variable Size i.e. Ln Assets. With inclusion of Size as control variable, the results of the coefficient $\gamma$ (Expected Earning Shock* Director Equity) are again significantly positive. It shows that each one percentage increase (decrease) in director equity (i.e. direct cash flow rights) increases (decreases) the responsiveness to Rs.100 industry earning shock (earnings variation) by Rs.2.38. Therefore, on average, high cash-flow right firm is more responsive than lower cashflow right firm by a percentage of Rs.2.38 and vice versa. These results show that difference of ownership plays an important and pivotal role in existence of tunneling in family business groups because the significant ownership difference highly affects the sensitivity to earning shock. 
Table 6: Sensitivity to Industry Profit Variations (Expected Earning Shock) by Direct Cash Flow Rights (Director Equity) (Dependent Variable: Gross Profit)

\begin{tabular}{|c|c|c|c|c|c|c|}
\hline \multirow[t]{2}{*}{ Model Variables } & \multicolumn{3}{|c|}{ Group Firms } & \multicolumn{3}{|c|}{ Standalone Firms } \\
\hline & A & B & $\mathrm{C}$ & $\mathrm{D}$ & $\mathrm{E}$ & $\mathrm{F}$ \\
\hline \multirow{2}{*}{$\begin{array}{l}\text { Expected Earning } \\
\quad \text { Shock }=\beta\end{array}$} & $0.9051^{* * *}$ & $0.5041^{* * *}$ & $4.311^{* * *}$ & $0.834^{* * *}$ & $0.811^{* * *}$ & -0.727 \\
\hline & $(0.0238)$ & $(0.0456)$ & $(0.671)$ & $(0.044)$ & $(0.059)$ & $(0.741)$ \\
\hline \multirow{2}{*}{$\begin{array}{c}\text { Expected Earning } \\
\text { Shock*Director } \\
\text { Equity }=\gamma\end{array}$} & $0.0274^{* * *}$ & $0.0238^{* * *}$ & $0.0285^{* *}$ & $0.0068^{* *}$ & $0.0070^{* *}$ & $0.0104^{* *}$ \\
\hline & $(0.002)$ & $(0.001)$ & $(0.003)$ & $(0.003)$ & $(0.004)$ & $(0.004)$ \\
\hline \multirow[t]{2}{*}{ Size $=\delta$} & & $0.255^{*}$ & 0.106 & & -0.162 & -0.277 \\
\hline & & $(0.153)$ & $(0.157)$ & & $(0.111)$ & $(0.159)$ \\
\hline \multirow{2}{*}{$\begin{array}{l}\text { Expected Earning } \\
\text { Shock*Size }\end{array}$} & & & $-0.165^{* * *}$ & & & $0.064^{* *}$ \\
\hline & & & $(0.029)$ & & & $(0.030)$ \\
\hline \multirow{2}{*}{$\begin{array}{l}\text { Expected Earning } \\
\text { Shock }^{*} \text { Age }\end{array}$} & & & $0.013^{* * *}$ & & & -0.006 \\
\hline & & & $(0.003)$ & & & $(0.004)$ \\
\hline Adjusted $\mathrm{R}^{2}$ & 0.96 & 0.92 & 0.91 & 0.93 & 0.91 & 0.92 \\
\hline
\end{tabular}

This Table 6 show the sensitivity to industry profit variations (i.e. expected earning shock) by direct cash flow rights (i.e. director equity). The column A \& D show the regression results of basic Model 2 without control variables for group firms and stand-alone firms respectively. The remaining columns $\mathrm{B}$ $\& C$ and $E \&$ F show the regression results of same model with different control variables like Age, Size and interactions terms with Expected Earnings for group firms and stand-alone firms respectively. The ${ }^{*}$ shows $\mathrm{p}<0.10$, ** shows $\mathrm{p}<0.05$ and ${ }^{* * *}$ shows $\mathrm{p}<0.01$. Parenthesis show standard errors.

The Column $\mathrm{C}$ includes all control variables and results are still significantly positive and consistent for coefficient $\gamma$ (Expected Earning Shock ${ }^{*}$ Director Equity). Although, the size and age of firms have significant effect on the firm's responsiveness (sensitivity) to earnings variations (shocks). However, the percentage of cash-flow rights mainly determines the degree of sensitivity. These findings supports the hypothesis of the study that firms having high (low) cash-flow rights are comparatively more (less) responsive. Further, resources are expropriated (tunneled) by majority shareholders or controlling owners from firms at low cash-flow rights level to firms at high cash-flow rights level in a family business group.

In Columns D, E and F; the same regression tests are repeated for standalone firms. In these columns, the regression results exhibit considerable effect of directors' shareholdings on responsiveness to shocks for non-group or standalone firms. However, the extent of responsiveness in non-group firms is comparatively less than family business group firms. This difference of responsiveness in stand-alone vs family business groups firms is due to difference of directors' shareholdings in standalone 
firms. It is also evident that the group firms are comparatively more responsive because resources are transferred or expropriated within group affiliated firms. Again, these results endorse the hypothesis regarding tunneling i.e resources are expropriated by controlling shareholders through transfer of resources from lower level firms to higher level firms in the family business group.

To summarize, the empirical results in Table 6 are significant and consistent with this expectation; where there is more ownership (equity) stake of the majority shareholder, there is less likelihood of expropriation or tunneling in that firm affiliated with family business group.

\section{Conclusion}

This study empirically investigates an important agency issue between majority (controlling owner) and minority shareholders in family business groups firms of Pakistan. By following the Bertrand et al. (2002), the study examines the responsiveness of firms to relative industry earnings shocks (profit variations). Further, it analyses the responsiveness of non-group (standalone) firms. By measuring the sensitivities of family business groups firms and non-group firms to earnings shocks in their industry; the study finds that majority shareholders expropriate minority shareholders by tunneling resources from low cash-flow right firms of family business groups.

Consistent with the adopted methodology, the empirical results highlight that about $15 \%$ resources are expropriated from low to high cash-flow rights family business groups firms. Moreover, in a family business group firm, 1 percent increase in shareholdings of directors, executives and related parties leads to 2.38 percent decrease in earnings of minority shareholders in low cash-flow rights firms of that business group. The results also show that non-group firms are less sensitive to earnings shocks in relative industry; thus, they have less chances of tunneling. It is also evident that size and age of firm significantly affect the responsiveness to earnings shocks. The results and findings remain significantly consistent even when control variables size and age are incorporated in the regression models.

The findings of study have policy implications for governance related regulation development to protect minority shareholders from tunneling in family business groups. The need to include more independent directors on boards of firms or implementation of strict measures to protect minority shareholders from majority shareholders is also evident through the results. The results highlights the importance of consciousness of minority shareholders while investing in family business group firm as compared to stand-alone firm in a similar industry. 


\section{References}

Almeida, H., Kim, C., \& Kim, H. B. (2015). Internal capital markets in business groups: Evidence from the Asian financial crisis. The Journal of Finance, LXX (6), 2539-2586.

Amjad, R. (1982). Private industrial investment in Pakistan 1960-1970, Cambridge: Cambridge University Press.

Ashraf, J., \& Ghani, W. (2004). Corporate governance, business group affiliation and firm performance: Descriptive evidence from Pakistan. Working Paper Series No. 05- 35, Centre for Management and Economic Research, Lahore University of Management Sciences, Lahore.

Baek, J., Kang, J., \& Lee, I. (2006). Business groups and tunneling: Evidence from private securities offerings (PSOs) by Korean Chaebols. The Journal of Finance, LXI (5), 2415-2449.

Baek, J., Kang, J., \& Park, K. (2004). Corporate governance and firm value: Evidence from the Korean financial crisis. Journal of Financial Economics, 71(2), 265-313.

Berkman, H., Cole, R.A., \& Fu, L.J. (2009). Expropriation through loan guarantees to related parties: Evidence from China. Journal of Banking $\mathcal{E}$ Finance, 33(1), 141-156.

Berle, A. A., \& Means, G.C. (1932). The Modern Corporation and Private Property. New York: Macmillan.

Bertrand, M., Mehta, P., \& Mullainathan, S. (2002). Ferreting out tunneling: An application to Indian business groups. Quarterly Journal of Economics, 117(1), 121-148.

Bertrand, M., \& Mullainathan, S. (2003). Pyramids. Journal of the European Economic Association, 1, 478-483.

Byun, H., Choi, S., Hwang, L., \& Kim, R.G. (2013). Business group affiliation, ownership structure, and the cost of debt. Journal of Corporate Finance, 23(C), 311-331.

Cheema, A. (2003). Corporate Governance in Pakistan: Issues and Concerns. NIPA Journal, 8(2), 7-18.

Cheung, Y., Jing, L., Lu, T., Rau, P.R., \& Stouraitis, A. (2009). Tunneling and propping up: An analysis of related party transactions by Chinese listed companies. Pacific-Basin Finance Journal, 17(3), 372-393.

Claessens, S., \& Burcin, B.Y. (2013). Corporate governance in emerging markets: A survey. Emerging Markets Review, 15(C), 1-33.

Claessens, S., Djankov, S., \& Lang, L.H.P. (2000). The separation of ownership and control in East Asian corporations. Journal of Financial Economics, 58(1-2), 81-112.

Demsetz, H., \& Lehn, K. (1985). The structure of corporate ownership: Causes and consequences. Journal of Political Economy, 93(6), 1155-1177.

Djankov, S., La Porta, R., Lopez-de-Silanes, F., \& Shleifer, A. (2008). The law and economics of self-dealing. Journal of Financial Economics, 88(3), 430-465. 
Faccio, M., Lang, L., \& Young, L. (2001). Dividends and expropriation. American Economic Review, 91(1), 54-78.

Fan, J.P.H., Wei, J.K.C., \& Xu, X. (2011). Corporate finance and governance in emerging markets: A selective review and an agenda for future research. Journal of Corporate Finance, 17(2), 207-214.

Friedman, E., Johnson, S., \& Mitton, T. (2003). Propping and tunneling. Journal of Comparative Economics, 31(4), 732-750.

Gao, L., \& Kling, G. (2008). Corporate governance and tunneling: Empirical evidence from China. Pacific-Basin Finance Journal, 16(5), 591-605.

Hamelin, A. (2011). Small business groups enhance performance and promote stability, not expropriation: Evidence from French SMEs. Journal of Banking and Finance, 35(3), 613-626.

Hoshi, T., Kashyap, A., \& Scharfstein, D. (1990). The role of banks in reducing the costs of financial distress in Japan. Journal of Financial Economics, 27(1), 67-88.

Hoshi, T., \& Kashyap, A. (2004). Japan's financial crisis and economic stagnation. Journal of Economic Perspectives, 18(1), 3-26.

Ikram, A., \& Naqvi, S.A.A. (2005). Family business groups and tunneling framework: Application and evidence from Pakistan. Working Paper Series No.05-41, Centre for Management and Economic Research, Lahore University of Management Sciences, Lahore.

Javid, A.Y., \& Iqbal, R. (2010). Corporate governance in Pakistan: Corporate valuation, ownership and financing. Working Paper Series No. 57, Pakistan Institute of Development Economics, Islamabad.

Jensen, M.C., \& Meckling, W.H. (1976). Theory of the firm: Managerial behaviour, agency costs and ownership structure. Journal of Financial Economics, 3(4), 305-360.

Jiang, G., Lee, C.M.C., \& Yue, H. (2010). Tunneling through inter corporate loans: The China experience. Journal of Financial Economics, 98(1), 1-20.

Johnson, S., La Porta, R., Lopez-de-Silanes, F., \& Shleifer, A. (2000). Tunneling. American Economic Review, 90(2), 22-27.

Johnson, S., Boone, P., Breach, A., \& Friedman, E. (2000). Corporate Governance in the Asian Financial Crisis. Journal of Financial Economics, 58(1-2), 141-186.

Kali, R., \& Sarkar, J. (2011). Diversification and tunneling: Evidence from Indian business groups. Journal of Comparative Economics, 39(3), 349-367.

Khanna, T., \& Palepu, K. (1997). Why focused strategies may be wrong for emerging markets. Harvard Business Review, 75(4), 41-51.

Khanna, T., \& Palepu, K. (2000). Is group affiliation profitable in emerging markets: An analysis of diversified Indian business groups. The Journal of Finance, 55(2), 867-891. 
Khanna, T., \& Yafeh, Y. (2007). Business groups in emerging markets: Paragons or parasites? Journal of Economic Literature, 45(2), 331-372.

La Porta, R., Lopez-de-Silanes, F., \& Shleifer, A. (1999). Corporate ownership around the world. The Journal of Finance, 54(2), 471-517.

La Porta, R., Lopez-de-Silanes, F., \& Shleifer, A. (2000). Investor protection and corporate governance. Journal of Financial Economics, 58(1-2), 3-27.

Lensink, R., \& Molen, R. (2010). Does group affiliation increase firm value for diversified groups? New evidence from Indian companies. Journal of Empirical Finance, 17(3), 332-344.

Mitton, T. (2002). A cross-firm analysis of the impact of corporate governance on the East Asian financial crisis. Journal of Financial Economics, 64(2), 215-241.

Morck, R., \& Nakamura, M. (2005). A frog in a well knows nothing of the ocean: A history of corporate governance in Japan. University of Chicago Press, Chicago.

Orbay, H., Yurtoglu, B.B. (2006). The impact of corporate governance structures on the corporate investment performance in Turkey. Corporate Governance: An International Review, 14(4), 349-363.

Peng, Q., John, K.C., \& Yang, Z. (2011). Tunneling or propping: Evidence from connected transactions in China. Journal of Corporate Finance, 17(2), 306-325.

Pindado, J., \& Requejo, I. (2015). Family business performance from a governance perspective: A review of empirical research. International Journal of Management Reviews, 17(3), 279-311.

Rahman, S. (1998). Who Owns Pakistan? Fluctuating fortunes of business Mughals, The University of Michigan.

Riyanto, Y.E., \& Toolsema, L.A. (2008). Tunneling and propping: A justification for pyramidal ownership. Journal of Banking $\mathcal{E}$ Finance, 32(10), 2178-2187.

White, L. (1974). Industrial Concentration and Economic Power in Pakistan. Princeton, NJ: Princeton University Press. 


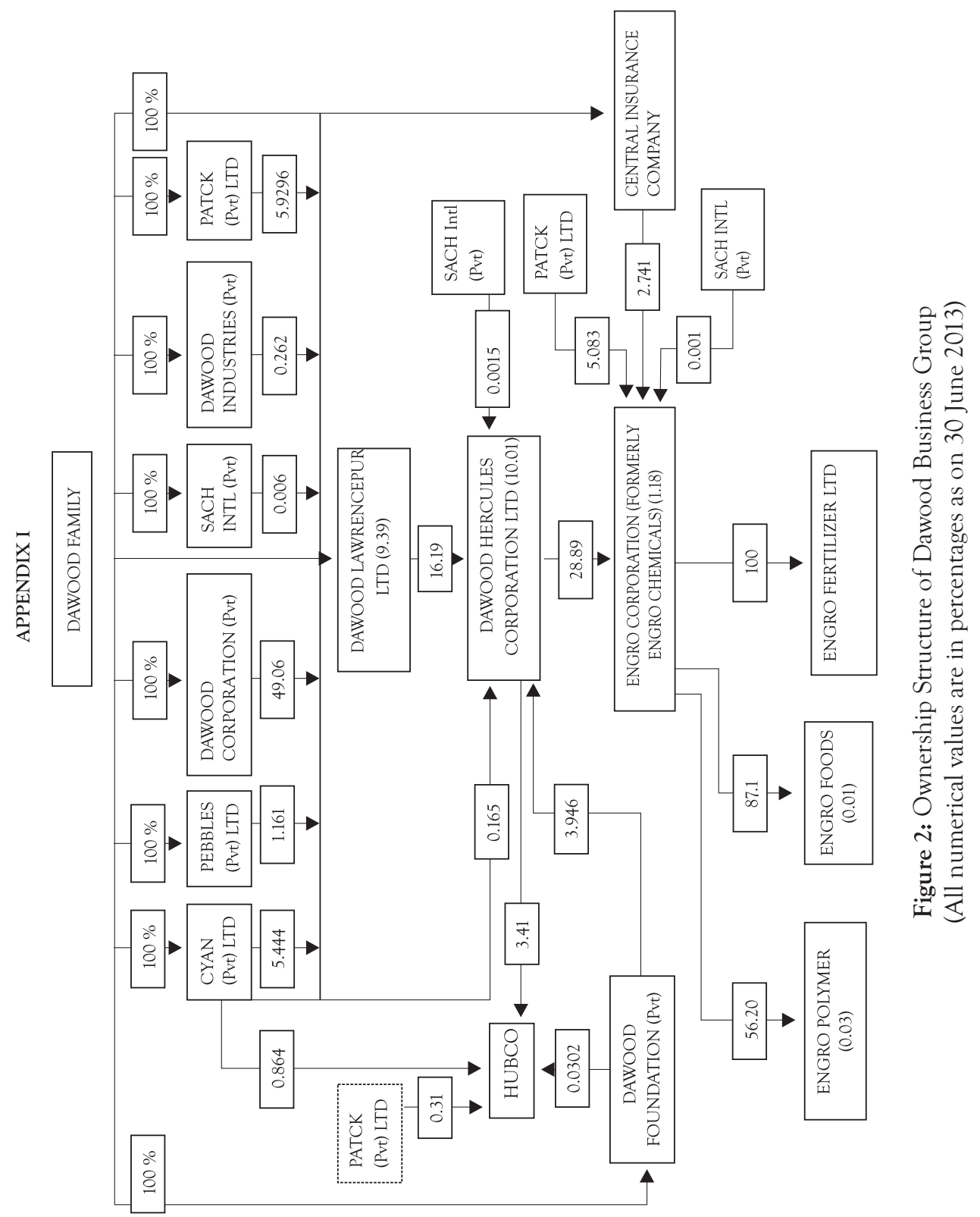


